\title{
The African Human Rights Architecture: Reflections on the Instruments and Mechanisms within the African Human Rights System
}

\author{
Victor Oluwasina Ayeni \\ Faculty of Law, Adekunle Ajasin University, Akungba-Akoko, Nigeria \\ Email: victorayeni7@gmail.com
}

How to cite this paper: Ayeni, V. O. (2019). The African Human Rights Architecture: Reflections on the Instruments and Mechanisms within the African Human Rights System. Beijing Law Review, 10, 302-316.

https://doi.org/10.4236/blr.2019.102019

Received: December 15, 2018

Accepted: March 22, 2019

Published: March 25, 2019

Copyright () 2019 by author(s) and Scientific Research Publishing Inc. This work is licensed under the Creative Commons Attribution International License (CC BY 4.0).

http://creativecommons.org/licenses/by/4.0/

(c) (i) Open Access

\begin{abstract}
This article examines and summarizes the normative and institutional mechanisms within the African human rights system. The article identifies some of the challenges facing the young human rights system in Africa such as lack of proper coordination, avoidable overlaps and duplication of functions, as well as limited capacity of, and limited access to, the various human rights protecting institutions. Against the backdrop of proliferation of human rights treaties and bodies on the African continent under the guise of creating binding instruments and judicial human rights bodies, the article argues that international human rights law has grown beyond the "hard law" versus "soft law" debate where only legally binding treaties and judgments of judicial tribunals alone create legal obligations for states; and that the solution to the protection of human rights in Africa has little to do with the number or nomenclature of the protection mechanisms but rather their effectiveness. This article is significant in view of the proliferation of human rights instruments and protection mechanisms in Africa and the challenge posed to the effectiveness of the mechanisms as a result of poor coordination and overlap of functions.
\end{abstract}

\section{Keywords}

Human Rights, Africa, Instruments, Mechanisms

\section{Introduction}

The desire to promote regional cooperation and decolonization in Africa prompted African elites to establish the Organization of African Unity in 1963. 
The Charter establishing the OAU focused on states sovereignty, territorial integrity and non-interferences in the affairs of states. ${ }^{1}$ Human rights were essentially relegated to the side-lines in the agenda of OAU (Viljoen \& Baimu, 2004). As a matter of policy, human rights issues were treated as matters falling within the exclusive purview of states, and individuals advocating such issues were considered subversive (Mangu, 2005). One way to sum up the human rights milieu under the OAU Charter is that the rights of states outweighed human and peoples' rights (Isanga, 2013). Thus, one notable achievement of the OAU is the political liberation and decolonization of African states (Maluwa, 2007). These failings together with the reality of globalization led to call for the amendment of the OAU Charter.

At the fourth extraordinary session of the OAU Assembly held in Sirte, Libya, on 9 September 1999, African Heads of State and Government agreed to form the African Union (AU) to replace the OAU. ${ }^{2}$ The Constitutive Act of the AU which replaced the OAU was adopted on 11 July 2000. It entered into force on 26 May 2002. While a number of human rights instruments were adopted by the OAU, the transition from the OAU to AU marked an important milestone in the history of human rights in Africa. The new founding instrument places human rights directly on the agenda of the AU (Heyns, 2004).

Against the above background, the African regional human rights system, also referred to as the "pan-continental human rights system in Africa" comprises of both normative and institutional components (Odinkalu, 2001). Under the auspices of the Organization of African Unity (OAU), now the African Union (AU), African states have adopted and ratified numerous human rights treaties. ${ }^{3}$ Together with the relevant soft law standards, these treaties make up the African human rights normative system. While the normative system consists of treaties and soft law standards, the institutional component comprises mechanisms for monitoring and supervising state's implementation of human rights treaties and standards. These mechanisms comprise independent expert committees as well as quasi-judicial and fully-fledged judicial institutions established by state parties to monitor and promote states' implementation of human rights treaty standards, and to provide redress for individuals whose rights under the treaties are violated by their states.

\section{Normative System}

The normative framework of African human rights system is based primarily on ${ }^{1}$ OAU Charter, art III

${ }^{2}$ Constitutive Act of the AU, Preamble.

${ }^{3}$ Some of the treaties adopted by member states of the OAU (now AU) include the OAU Convention Governing the Specific Aspects of Refugee Problems in Africa 1969, Cultural Charter for Africa 1976, African Charter on the Rights and Welfare of the Child 1990, Protocol to the African Charter on Human and Peoples' Rights on the Establishment of the African Court on Human and Peoples' Rights 1998, the Constitutive Act of the African Union 2000, Protocol to the African Charter on Human and Peoples' Rights on the Rights of Women in Africa 2003, Convention on Prevention and Combating Corruption 2003, African Charter on Democracy, Elections and Good Governance 2007, and the AU Convention for the Protection of and Assistance of Internally Displaced Persons 2009. 
the African Charter on Human and Peoples' Rights (Charter) (Ayeni, 2016). At July 2017, all the 55-member countries of the AU except Morocco have ratified the Charter. ${ }^{4}$ The Charter is the primary instrument for the promotion and protection of human rights in Africa, and its adoption marks the beginning of organized commitment to human rights promotion and protection in Africa $(\mathrm{Gu}-$ medze, 2003).

The Charter has been hailed as a unique human rights instruments (Mutua, 1995). The Charter, it is argued, responds to "African concerns, African traditions and African conditions" (Boven, 1986). The Charter is one of the few human rights instruments that combines the first-generation rights, that is civil and political rights, and the second general rights, that is economic, social and cultural rights (ESCRs), in a single document, and both these generations of rights are made justiciable. The Charter is one of the foremost binding international human rights instruments to have directly incorporated the concept of peoples' rights, solidarity rights or collective rights (Kiwanuka, 1988). Articles 19 to 24 of the Charter guarantee peoples' rights to right to equality, existence, free disposal of wealth and natural resources, rights to development, peace and security as well as a right to a generally satisfactory environment. Unlike some international human rights treaties, provisions of the Charter cannot be derogated from even during national emergencies (Commission nationale des droits de l'Homme et des libertés $v$ Chad). ${ }^{5}$

In spite of its distinctive features, the Charter has been criticised on a number of grounds. For instance, the Charter has been criticised for its normative deficiency in relation to protection of vulnerable groups such as women, children and persons with disability (Viljoen, 2012). The presence of limitation clauses, also referred to as "claw-back clauses" in articles 6, 8, 9, 10, 11, 12, 13 and 14 among other provisions of the Charter, casts doubt on the normative scope and value of a number of its provisions (Singh, 2009). Many commentators have expressed concerns that the language of individual duty in the Charter could provide leeway for states to detract from its obligations under the Charter (Cohen, 1993). Thankfully, a number of these shortcomings have been "neutralized" through creative interpretation of the Charter by the African Commission (Heyns, 2001).

Of course, not all shortcomings of the Charter can be remedied through creative interpretation, even by the most activist human rights tribunal. As a result, the "need for reform" has been one common theme in most academic papers assessing the effectiveness of the Charter. In order to address the normative shortcomings of the Charter, the OAU/AU has adopted the Protocol on the Rights of Women in Africa (Maputo Protocol). The African Charter, the Maputo

${ }^{4}$ African Union "List of countries which have signed, ratified/acceded to the African Charter on Human and people's rights"

https://au.int/sites/default/files/treaties/7770-sl-african_charter_on_human_and_peoples_rights_2.p df (accessed 31 July 2017).

5(2000) AHRLR 66 (ACHPR 1995) para 21. 
Protocol, together with the Protocol to the African Charter on the establishment of the African Court, may appropriately be referred to as the "African Charter system". The Maputo Protocol was adopted on 11 July 2003 in Maputo, the capital city of Mozambique. After achieving 15 ratifications, the Protocol entered into force on 25 November 2005. The Maputo Protocol was adopted to eliminate three evils: discrimination against women, traditional practices which are harmful to women, and violence against women (Odinkalu, 2002; Banda, 2006; Viljoen, 2009). The Maputo Protocol speaks to African concerns and situates the Convention on the Elimination of All forms of Discrimination against Women (CEDAW) within African reality (Ayeni, 2011). Like the African Charter, the Maputo Protocol "blazed a trail" in a number of areas such as the right to medical abortion, ${ }^{6}$ prohibition of domestic violence, ${ }^{7}$ and protection against HIV infections. ${ }^{8}$

Beyond the African Charter system, the normative framework of the African human rights system includes other regional human rights treaties such as the African Charter on the Rights and Welfare of the Child (African Children's Rights Charter). ${ }^{9}$ There are also other treaties which relate to pertinent human rights issues such as protection of refugees and internally displaced persons, ${ }^{10}$ conservation of nature and environment, ${ }^{11}$ and promotion of democracy, elections and good governance. ${ }^{12}$ The normative component of the African human rights system also covers treaties establishing political organs whose mandate include the promotion and protection of human rights in Africa. ${ }^{13}$ The normative system also comprises "soft law" standards. There are many of these technically "non-binding" human rights instruments in Africa, and they constitute an integral component of the African human rights system. ${ }^{14}$ Shelton demonstrates how these often-underestimated soft laws "harden" and become even more compelling for compliance in certain situations than the so-called "hard laws" (Shelton, 2007).

\section{Institutional Mechanisms}

In 2018, the African human rights protection system comprises both specialised

\footnotetext{
${ }^{6}$ Maputo Protocol, art 14(2).

${ }^{7}$ Maputo Protocol, art 4(2).

${ }^{8}$ Maputo Protocol, art 14(1).

${ }^{9}$ African Union "OAU/AU Treaties, Conventions, Protocols \& Charters"

http://www.au.int/en/treaties (accessed 24 September 2016).

${ }^{10}$ OAU Convention Governing Specific Aspects of Refugee Problems in Africa 1969; AU Convention for the Protection and Assistance of Internally Displaced Persons 2009.

${ }^{11} \mathrm{OAU}$ Convention on the Conservation of Nature and Natural Resources 1969; African Convention on the Conservation of Nature and Natural Resources 2003.

${ }^{12}$ African Charter on Democracy, Election and Governance 2007.

${ }^{13}$ See for instance the Constitutive of African Union 2000; Treaty Establishing the African Economic Community 1991; Protocol to the Treaty Establishing the Pan-African Parliament 2001; Statute of the Economic, Social and Cultural Council of the African Union 2004; and Protocol relating to the Establishment of the Peace and Security Council of the African Union 2002.

${ }^{14}$ Examples of soft laws in Africa include the Solemn Declaration on Gender Equality in Africa 2004, Banjul Declaration 2006, Declaration on the Principles Governing Democratic Elections in Africa 2002, and Declaration on Unconstitutional Change of Government 2002.
} 
human rights tribunals and other $\mathrm{AU}$ organs that contribute to the promotion and protection of human rights in Africa. The tribunals which are generally regarded as the primary mechanisms for enforcement and implementation of human rights in Africa include the African Commission, the African Court and the African Committee of Experts on the Rights and Welfare of the Child (African Children's Rights Committee). Each of the main organs of the AU contributes towards realizing human rights in Africa. The Constitutive Act of the African Union (AU) spells out the responsibilities of these organs with regards to human rights (Lloyd \& Murray, 2004).

Due to the centrality of human rights to the operations of the AU, all organs of the AU contribute towards the realization of its human rights agenda. Thus, political organs such as the AU assembly, the Executive Council, Pan-African Parliament, the AU Commission and the Peace and Security Council (PSC) perform various functions relevant to the promotion and protection of human rights of the African continent. For example, the AU Assembly, being the supreme organ of the $\mathrm{AU}$, is responsible for adopting and amending human rights treaties. The AU Assembly also adopts non-binding soft law standards such as resolutions, declaration and guiding principles on specific human rights themes such as gender equality, employment and poverty alleviation. ${ }^{15}$ The Assembly also contributes to monitoring implementation of these soft law standards.

The Executive Council is responsible for monitoring implementation of decisions of the AU Assembly including consideration of Activity Reports of the African Commission. The Council also has the responsibility of monitoring judgments of the African Court. ${ }^{16}$ The role of the AU Commission, as the "heart" of the pan-African continental body, cannot be stressed strongly enough. The Commission comprises eight departments. Two of these departments-the Political Affairs as well as Social Affairs departments-play vital roles in the realization of human rights within the AU. The Peace and Security Council (PSC) is the foremost institution for the maintenance of regional peace, security and stability in Africa. ${ }^{17}$ Promotion and protection of human rights and fundamental freedoms occupy a central place in the objectives and principles of the PSC. ${ }^{18}$ The Protocol establishing the PSC clearly mandates the Council to work closely with the African Commission. ${ }^{19}$ Although the African Peer Review Mechanism (APRM) process is not all about human rights, it has been argued that human rights occupy a foremost position in the process (Killander, 2008). As at January 2016, 37 countries have acceded voluntarily to the APRM process, and 17 of

\footnotetext{
${ }^{15}$ See for instance Solemn Declaration on Gender Equality in Africa, adopted in July 2004.

${ }^{16}$ Rules of Procedure of the African Court, rule 64.

${ }^{17}$ Protocol relating to the Establishment of the Peace and Security Council of the African Union. It was adopted on 10 July 2002 and entered into force on 26 December 2003.

${ }^{18}$ Peace and Security Council Protocol, art 3 (f) \& 4(c).

${ }^{19}$ Peace and Security Council Protocol, art 19; Rules of Procedures of the African Commission, rules $80 \& 84$.
} 
these have been peer-reviewed..$^{20}$ As earlier stated, the three main regional human rights tribunals in Africa are the African Commission, the African Court and the African Children's Rights Committee. Below is an overview of the three main regional human rights tribunals in Africa.

\subsection{African Commission}

The African Commission on Human and Peoples' Rights (African Commission) was established under the African Charter for the dual purposes of promoting and protecting the rights enshrined in the Charter. ${ }^{21}$ It has been argued that the promotional and protective roles of the Commission are interrelated and complementary. The African Commission comprises 11 members selected from among "Africans personalities of the highest reputation". 22 Members of the Commission are elected by the AU Assembly through secret ballot from a list of nominees presented by state parties to the Charter. ${ }^{23}$ Members of the Commission serve in their personal capacity, ${ }^{24}$ and no two nationals of a state party to the Charter may serve on the Commission at the same time. ${ }^{25}$ Members of the Commission are elected for a term of six years, renewable indefinitely. All members of the Commission work on a part-time basis, and this has been identified as one of the major obstacles confronting the Commission. ${ }^{26}$

The functions of the African Commission are set out in articles 45, 55 and 62 of the Charter. While the Charter merely provided the skeletal structure for the functioning of the African Commission, the Commission through its practice and procedure has elaborated on its mandate. In addition to performing other tasks assigned to it by the AU Assembly, the African Commission has three key aspects to its mandate under the Charter: promotion of human and peoples' rights, interpretation of the provisions of the Charter and protection of human and peoples' rights. ${ }^{27}$ The Charter provides a checklist of what the promotional mandate of the Commission entails. ${ }^{28}$ In terms of its protective mandate, the African Commission has received, assessed and considered inter-state and individual communications submitted in terms of articles 47 and 55 of the Charter.

${ }^{20}$ Remarks by Uhuru Kenyatta, Chairperson of the African Peer Review (APR) Forum, during the Special Summit of the Committee of Heads of State and Government participating in the African Peer Review Mechanism in Addis Ababa, Ethiopia, 29 January 2016, available at https://allafrica.com/stories/201602011532.html (accessed 4 February 2019).

${ }^{21}$ African Charter, art 30.

${ }^{22}$ African Charter, art 31.

${ }^{23}$ African Charter, art 33.

${ }^{24}$ African Charter, art 31(2)

${ }^{25}$ African Charter, art 32.

${ }^{26}$ Opening speech by the Chairperson of the African Commission on Human and Peoples' Right at the opening ceremony of the 52nd ordinary session of the African Commission on Human and Peoples' Rights, Yamoussoukro, Côte d'Ivoire. The speech is available at http://www.achpr.org/sessions/52nd/speeches/atoki-opening-speach/ (accessed 26 September 2016). ${ }^{27}$ African Charter, art 45. See also African Commission on Human and Peoples' Rights "About ACHPR" http://www.achpr.org/about/ (accessed 6 July 2016).

${ }^{28}$ African Charter, art 45(1) (a)-(c). 


\section{1) Communication procedure}

The communication procedure of the African Commission may be divided broadly into inter-state and individual communication procedures. In terms of inter-state communications, the Charter provides that if a state party has good reasons to believe that another state party has violated the provisions of the Charter, the state may draw the attention of the offending state to the violation through a written communication. ${ }^{29}$ The communication may also be submitted directly to the African Commission, provided a copy of the communication is forwarded to the Chairperson of the AU Commission and the State Party concerned..$^{30}$ As at July 2017, the African Commission has received three inter-state communications, and decided only two, namely: DRC $v$ Burundi, Rwanda and Uganda $^{31}$ and Communication 422/12 Sudan $v$ South Sudan. ${ }^{32}$

In the earliest years of its operations, the Commission's powers to receive and consider individual communications was called into question (Odinkalu, 2010; Benedek, 1993). The grounds of the legal challenge and scepticisms relate to the ambiguity of the individual communications provisions of the Charter. Article 55 of the Charter relating to "other communications" states that the Secretary of the African Commission shall make "a list of the communications other than those of States parties to the present Charter and transmit them to the members of the Commission, who shall indicate which communications should be considered by the Commission." ${ }^{33}$ In order for a communication to be admissible by the Commission, the Charter in article 56 prescribes a set of criteria (admissibility criteria) which the communication must satisfy.

From 1994 when the African Commission published its first activity report that contains findings on individual communications handled by the Commission up to November 2017, the Commission has received 659 communications, finalized 446 of which more than 100 are on merits, and the Commission has found violations in 83 communications, involving 27 states that are parties to the Charter. $^{34}$ As at November 2017, the Commission was having 221 pending communications; five of which were at seizure stage, 177 at admissibility and 38 on merits.

\footnotetext{
${ }^{29}$ African Charter, art 47.

${ }^{30}$ African Charter, art 49.

${ }^{31}$ (2004) AHRLR 19 (ACHPR 2003).

${ }^{32}$ Inter-session activity report of Hon Commissioner Lucy Asuagbor, Chairperson of the Working Group on Communications, presented at the 61st ordinary session of the African Commission on Human and Peoples' Rights, Banjul, The Gambia, 1-15 November 2017

http://www.achpr.org/files/sessions/61st/inter-act-reps/293/eng_comm_asuagbor_ar_wgc_chair_61 st_os.pdf (accessed 12 December 2017). The third inter-state communication submitted to the African Commission is Communication 478/14 Djibouti v Eritrea, seized during the 17th extraordinary session of the Commission in February 2015. No decision has yet been reached on this communication.

${ }^{33}$ African Charter, art 55.

${ }^{34}$ Inter-session activity report (June-November 2017) of Hon Commissioner Lucy Asuagbor, Chairperson of the Working Group on Communications, presented at the 61st ordinary session of the African Commission on Human and Peoples' Rights, Banjul, The Gambia, 1-15 November 2017 http://www.achpr.org/files/sessions/61st/inter-act-reps/293/eng_comm_asuagbor_ar_wgc_chair_61 st_os.pdf (accessed 12 December 2017).
} 


\section{2) States' obligation to comply with decisions of the African Commission}

The decisions and remedial orders of the African Commission are generally considered as "non-binding". As early as 1997, the problem of non-compliance by states with remedial orders of the Commission had been identified. ${ }^{35}$ For this reason, chiefly, the African Commission was branded as "impotent" and "incompetent" (Mangu, 2005). In a study conducted in 2004, Viljoen and Louw found that only 14 percent of the decisions of the African Commission in individual communications have been complied with by states (Viljoen \& Louw, 2007). Partial compliance was recorded in 32 percent while non-compliance was found in 13 cases representing 30 percent of the finalized cases (Viljoen \& Louw, 2007). States have generally argued that decisions of the Commission are no more than "mere recommendations" which they may or may not implement (Murray \& Long, 2015). Contrary to states' proposition above, it may be argued that the legal status of the findings of the African Commission changes once the Activity Reports embodying the decisions have been approved by the AU Assembly or very recently the Executive Council (Viljoen \& Louw, 2004). The binary categorization of the decisions of the African Commission as either binding or non-binding has been called to question in recent studies. Murray and Long referred to it as "a blunt tool" (Murray \& Long, 2015).

Generally, international human rights law has grown beyond the level where only explicitly binding instruments create legal obligations. It is argued that states have an obligation to implement decisions of the African Commission, regardless of the explicit legal status of those decisions. This is because obligations arising from individual communications are not new obligations created by the Commission's decisions; they are obligations assumed by states as a consequence of ratifying the Charter. The Charter gives the Commission the mandate to interpret provisions of the Charter. All that the African Commission does when it decides an individual communication is to interpret and define a state's obligation under the Charter in relation to a given set of facts presented in the communication. It is therefore argued that states' obligation to implement decisions of the African Commission, once approved by the AU Assembly, cannot be separated from the existing obligation of states to implement provisions of the Charter.

This argument is based on the "interpretive authority" of the Commission, otherwise referred to as res interpretata, which has been developed significantly in the European human rights system (Bodnar, 2014). The res interpretata theory, in the African context, implies that states are bound by interpretations given to the Charter by the African Commission, even in decisions concerning violations that occurred in other countries that are state parties to the Charter (Zysset, 2017). Within the purview of the res interpretata theory, it is argued that

${ }^{35}$ African Commission "Non-compliance of state parties to adopted recommendations of the African Commission: A legal approach"

http://hrlibrary.umn.edu/africa/non-compliance.html (accessed 4 February 2019). See also R Murray \& M Evans Documents of the African Commission on Human and Peoples Rights (2001) 758. 
the interpretive content of a decision given by the African Commission binds all state parties to the Charter. Thus, in order to clarify the binding effect of the Commission's decisions especially on other states, a distinction needs to be made between the "decisional content" and the "interpretive content" of the Commission's findings. With regard to the defaulting state, it is argued that both the decisional and interpretive contents are binding, as the Commission's authority to issue the decision flows directly from the Charter. Thus, states that are subjects of a decision from the Commission ought to accept the decision as binding, the decision being an extension or elaboration of their obligations under the Charter.

\subsection{African Court}

The Protocol Establishing the African Court on Human and Peoples' Rights (African Court Protocol) was adopted on 10 June 1998, and entered into force 25 January $2004 .{ }^{36}$ As at 15 June 2017, 30 member-states of the AU have ratified the African Court Protocol. ${ }^{37}$ The seat of the Court is in Arusha, Tanzania. The African Court was established primarily to complement the protective mandate of the African Commission. ${ }^{38}$ Unlike the African Commission, decisions of the Court are unequivocally binding on state parties. ${ }^{39}$ The African Court was established in anticipation that the Court, unlike the African Commission, will demonstrate greater clarity in framing its remedies, develop a more comprehensive procedure for implementation of its judgments, promote openness in carrying out its protective mandate, adopt effective measures for dealing with urgent cases, raise the profile and visibility of human rights adjudication on the continent, and ensure that cases are finalized with dispatch.

The African Court comprises 11 judges elected by the AU Assembly from member states of the AU. This raises a fundamental question as to whether the Assembly can elect onto the Court nationals of non-state party to the Court's Protocol. While only state parties to the Protocol may nominate candidates for election into the Court, it seems perfectly possible for nationals of non-state parties to be elected into the Court. ${ }^{40}$ In 2017, all judges of the Court are nationals of states that have ratified the Protocol. ${ }^{41}$ In the election of judges, the Protocol re-

\footnotetext{
${ }^{36}$ African Union "Protocol to the African Charter on Human and Peoples' Rights on the Establishment of an African Court on Human and Peoples' Rights" http://www.au.int/en/treaties/protocol-african-charter-human-and-peoples-rights-establishment-afr ican-court-human-and (accessed 16 October 2016).

${ }^{37}$ African Union "List of countries which have signed, ratified/acceded to the Protocol to the African Charter on Human and Peoples' Rights on the Establishment of an African Court on Human and Peoples" Rights'

https://au.int/sites/default/files/treaties/7778-sl-protocol_to_the_african_charter_on_human_and_p eoplesrights_on_the_estab.pdf (accessed 28 August 2017).

${ }^{38}$ African Court Protocol, art 2.

${ }^{39} 2010$ Rules of Procedure of the African Court, rule 61(5).

${ }^{40}$ African Court Protocol, art 12(1).

${ }^{41}$ African Court "Current judges" http://www.african-court.org/en/index.php/judges/current-judges (accessed 12 February 2018).
} 
quires due consideration to be given to "adequate gender representation" ${ }^{42}$ As at July 2017, the African Court comprises six male and five female judges.

The African Court's contentious and advisory jurisdiction is wider than that of the African Commission. Its contentious jurisdiction for instance covers all disputes regarding the interpretation and application of the Charter, the Court's Protocol and other human rights instruments ratified by a state that is party to a case before it. ${ }^{43}$ Any of the following entities has direct access to the Court: the African Commission, state parties to the Court's Protocol, any African Intergovernmental organization, and natural as well as legal persons from states that have made a declaration pursuant to article 34(6) of the Court's Protocol. ${ }^{44}$

In order for any case submitted to the African Court to be admissible, the case must satisfy the admissibility requirements stipulated in article 56(1) to 56(7) of the Charter. ${ }^{45}$ In addition to this, an NGO intending to submit a case against any of the seven states that have made the article 34(6) must have been granted "observer status" by the African Commission. ${ }^{46}$ As at November 2017, the African Commission has granted observer status to a total of 477 NGOs. ${ }^{47}$ The African Court may apply both the Charter and other relevant international human rights treaties ratified by a state while adjudicating on a matter involving the state. ${ }^{48}$

Judgments of the Court are final and binding on states. All state parties to the Court's Protocol undertake to comply with judgments of the Court and ensure their execution within the time stipulated by the Court. ${ }^{49}$ While the AU Assembly has responsibility for ensuring that judgments of the Court are complied with, the Executive Council has the duty of following up the status of implementation of the Court's decisions..$^{50}$ The African Court has a duty to submit to the AU Assembly on a yearly basis a report of its activities in the preceding year. Specifically, the Court is required to disclose to the Assembly or any other relevant organs of the $\mathrm{AU}$, states that have failed to comply with its judgments. ${ }^{51}$

\subsection{African Children's Rights Committee}

The African Children's Rights Committee was established under the African Charter on the Rights and Welfare of the Child, adopted on 11 July 1990, and entered into force 29 November $1999 .^{52}$ The Committee comprises 11 members elected by the AU Assembly. ${ }^{53}$ The Committee was formally inaugurated in April

${ }^{42}$ African Court Protocol, art 12(2).

${ }^{43}$ African Court Protocol, art 3.

${ }^{44}$ African Court Protocol, art 5.

${ }^{45}$ African Court Protocol, art 6.

${ }^{46}$ African Court Protocol, art 5(3).

${ }^{47}$ African Commission on Human and Peoples' Rights "Network: Non-governmental organizations" http://www.achpr.org/network/ (accessed 30 November 2017).

${ }^{48}$ African Court Protocol, art 3(1) and 7.

${ }^{49}$ African Court Protocol, art 30.

${ }^{50}$ African Court Protocol, art 29.

${ }^{51}$ African Court Protocol, art 31.

${ }^{52}$ The African Children's Rights Charter was adopted on 11 July 1990, and entered into force 29 November 1999.

${ }^{53}$ African Children's Rights Charter, art 33. 
2002. It is headed by a Chair and three Vice Chairs elected by members from among themselves. The Committee has three main functions: promoting and protecting the rights in the African Children's Rights Charter; monitoring the implementation of the Charter; and interpreting the provisions of the Charter. ${ }^{54}$ It is also empowered to receive individual communications. ${ }^{55}$

As at 31 December 2015, the Committee has received four communications against state parties and has finalized only three-IHRDA and OSJI $v$ Kenya, ${ }^{56}$ Hansungule $v$ Uganda, ${ }^{57}$ and the Centre for Human Rights and RADDHO $v$ Senegal. ${ }^{58}$ The Committee in October 2016 finalised one of the communications submitted to it through amicable settlement. ${ }^{59}$ Even though decisions of the Committee in individual communications are recommendatory in nature, it is argued that states have a legal obligation to implement them. As argued earlier in relation to the African Commission, obligations arising from individual communications are not new obligations created by the Committee's decisions; they are obligations assumed by states as a consequence of ratifying the African Human Rights Charter and the African Children's Rights Charter.

\section{Emerging Architecture of Regional HRTs in Africa}

In addition to the three main human rights tribunals discussed above, other African regional human rights bodies have been "created" but none have been operationalized. ${ }^{60}$ For instance, the AU Constitutive Act established a Court of Justice, and provides that the composition and functions of the Court shall be defined by member states in a separate protocol. ${ }^{61}$ The Protocol on the African Court of Justice was adopted on 11 July $2003 .{ }^{62}$ While the Protocol on the African Court of Justice was yet to enter into force, ${ }^{63}$ the $\mathrm{AU}$ in 2008 decided to create a new judicial institution, the African Court of Justice and Human Rights, thus merging the African Court of Justice with the African Court on Human and Peoples' Rights. ${ }^{64}$ The Protocol merging the two courts-the Protocol on the

\footnotetext{
${ }^{54}$ African Children's Rights Charter, art 42.

${ }^{55}$ African Children's Rights Charter, art 44.

${ }^{56}$ Communication 002/09 IHRDA and OSJI (on behalf of children of Nubian descent in Kenya) $v$ Kenya, decided by the African Children's Rights Committee on 22 March 2011.

${ }^{57}$ Communication 2/2009 Hansungule and Others (on behalf of children in Northern Uganda) $v$ Uganda. This communication was decided at the Committee's 21st ordinary session, 15-19 April 2013.

${ }^{58}$ Centre for Human Rights and La Rencontre Africaine pour la Defense des Droits de l'Homme $v$ Government of Senegal decided by the African Children's Rights Committee on 15 April 2004.

${ }^{59}$ African Children's Rights Committee "Amicable Settlement on Communication No. 004"

http://www.acerwc.org/amicable-settlement-on-communication-no-004/ (accessed 27 November 2016). See in Communication: No. 004/Com/001/2014 Institute for Human Right and Development in Africa v Malawi.

${ }^{60}$ Protocol on the African Court of Justice 2003; the Protocol on the Statute of the African Court of Justice and Human Rights 2008.

${ }^{61}$ AU Constitutive Act, art 18.

${ }^{62}$ African Union “OAU/AU Treaties, Conventions, Protocols \& Charters"

http://www.au.int/en/treaties (accessed 24 September 2016).

${ }^{63}$ The Protocol entered into force on 11 February 2009.

${ }^{64}$ Protocol on the Statute of the African Court of Justice and Human Rights, arts $1 \& 2$.
} 
Statute of the African Court of Justice and Human Rights-was adopted on 1 July 2008 but has not secured the necessary ratification to enable it come into force. ${ }^{65}$

While waiting for the Protocol on the Statute of the African Court of Justice and Human Rights to enter into force, the AU on 27 June 2014 adopted the Protocol on Amendments to the Protocol on the Statute of the African Court of Justice and Human Rights (Malabo Protocol). The Malabo Protocol changed the name of the African Court of Justice and Human Rights to "African Court of Justice and Human and Peoples' Rights", ${ }^{66}$ and extended the jurisdiction of the Court to include international crimes. ${ }^{67}$ The Malabo Protocol also vests on the yet to be established court the jurisdiction to entertain matters or appeals arising from agreements concluded by international organizations recognized by the AU. ${ }^{68}$ Such international organizations include regional economic communities (RECs). This raises the question whether parties aggrieved with decisions of the ECOWAS Court of Justice, the East African Court of Justice and the SADC Tribunal could appeal to the new Court once the founding Protocol enters into force but this is still to be determined. It is also not yet clear how the multi-chamber Court established under the Malabo Protocol would operate. Article 4 of the Malabo Protocol states that the Court, if and when finally, operationalized, will complement the protective mandate of the African Commission. In addition to serving as a human rights court for Africa, the Court will function also as a court of justice of the $\mathrm{AU}$ and as an African regional criminal court.

\section{Conclusion}

This article examines the instruments and mechanisms that constitute the African human rights architecture. It argues that Africa currently has three main bodies that perform primarily the function of adjudicating human rights complaints at the continental level. The article is limited to the three main regional human rights mechanisms in Africa. The article also does not examine mechanisms established at the sub-regional level in Africa for the adjudication of human rights or human rights related claims. Future research may thus explore the contributions of political organs within the $\mathrm{AU}$ and the various sub-regional courts to the protection of human rights in Africa.

While two of the mechanisms examined in the article-the African Commission and the African Children's Rights Committee-are quasi-judicial in nature, the African Court has the full character and powers of a court. As at 2018, discussions are focused on how to restructure the African human rights architec-

${ }^{65}$ African Union "OAU/AU treaties, conventions, protocols \& charters" http://www.au.int/en/treaties (accessed 27 November 2016).

${ }^{66}$ Protocol on Amendments to the Protocol on the Statute of the African Court of Justice and Human Rights (2004), art 8.

${ }^{67}$ Protocol on Amendments to the Protocol on the Statute of the African Court of Justice and Human Rights (2014), art 3(1).

${ }^{68}$ Protocol on Amendments to the Protocol on the Statute of the African Court of Justice and Human Rights (2014), art 3(2). 
ture through the establishment of a multi-chamber court; however, the Protocols containing these reforms are yet to enter into force. The solution to the protection of human rights in Africa has little to do with the number of the protection mechanisms but rather their effectiveness. Notwithstanding the proliferation of bodies with human rights mandate, the $\mathrm{AU}$ is yet to adequately mainstream human rights into its processes and programmes. This has resulted in lack of coordination and collaboration among the various AU organs. Avoidable overlaps and duplication of functions are commonplace. There is also the problem of limited capacity of, and limited access to, the various human rights-protecting institutions.

Decisions and reparation orders of the African Commission and those of the African Children's Rights Committee are generally considered as "non-binding" and recommendatory. The article argues that, contrary to the proposition above, the legal status of the findings of the African Commission changes once the Activity Reports embodying the decisions have been approved by the AU Assembly or very recently, the Executive Council. The article also argues that international human rights law has grown beyond the level where only binding instruments create legal obligations. States have an obligation to implement decisions of all duly constituted human rights bodies, regardless of the legal status of those decisions and whether the decisions are described as binding or recommendatory. The obligation to comply with decisions of HRTs is based in part on the principle of pacta sunt servanda. Obligations arising especially from individual communications are not new obligations created by the HRTs' decisions; they are "subsidiary obligations" assumed by states as a consequence of ratifying various human rights instruments.

\section{Conflicts of Interest}

The author declares no conflicts of interest regarding the publication of this paper.

\section{References}

Ayeni, V. O. (2011). Domestic Impact of the African Charter on Human and Peoples' Rights and the Protocol on the Rights of Women in Africa: A Case Study of Nigeria (p. 14). Unpublished LLM Dissertation, Pretoria: University of Pretoria.

Banda, F. (2006). Blazing a Trail: The African Protocol on Women's Rights Comes into Force. Journal of African Law, 50, 72-84. https://doi.org/10.1017/S0021855306000076

Benedek, W. (1993). The African Charter and Commission on Human and Peoples' Rights: How to Make It More Effective. Netherlands Quarterly of Human Rights, 11, 25-40. https://doi.org/10.1177/016934419301100103

Bodnar, A. (2014). Res Interpretata: Legal Effect of the European Court of Human Rights' Judgments for Other States than Those Which Were Party to the Proceedings. In Y. Haeck, \& E. Brems (Eds.), Human and Civil Liberties in the 21st Century (pp. 223-262). Dordrecht: Springer. https://doi.org/10.1007/978-94-007-7599-2_10

Boven, T. (1986). The Relations between Peoples' Rights and Human Rights in the African Charter. Human Rights Law Journal, 7, 186.

Cohen, R. (1993). Endless Teardrops: Proleg-Omena to the Study of Human Rights in 
Africa. In R. Cohen, G. Hyden, \& W. Nagan (Eds.), Human Rights and Governance in Africa. Gainesville: University Press of Florida.

Gumedze, S. (2003). Bringing Communications before the African Commission on $\mathrm{Hu}$ man and Peoples' Rights. African Human Rights Journal, 3, 119.

Heyns, C. (2001). The African Regional Human Rights System: In Need of Reform? African Human Rights Law Journal, 2, 157.

Heyns, C. (2004). The African Human Rights System: The African Charter. Penn State Law Review, 108, 681.

Isanga, J. M. (2013). The Constitutive Act of the African Union, African Courts and the Protection of Human Rights: New Dispensation? Santa Clara Journal of International Law, 1, 271.

Killander, M. (2008). The African Peer Review Mechanism and Human Rights: The First Reviews and the Way Forward. Human Rights Quarterly, 30, 41-75. https://doi.org/10.1353/hrq.2008.0011

Kiwanuka, R. (1988). The Meaning of Peoples' Rights in the African Charter on Human and Peoples' Rights. American Journal of International Law, 80, 80.

Lloyd, A., \& Murray, R. (2004). Institutions with Responsibility for Human Rights Protection under the African Union. Journal of African Law, 48, 165-186. https://doi.org/10.1017/S0021855304482035

Maluwa, T. (2007). From the Organization of African Unity to the African Union: Rethinking the Framework for Inter-State Cooperation in Africa in the Era of Globalisation. University of Botswana Law Journal, 5, 10.

Mangu, A. M. B. (2005). The Changing Human Rights Landscape in Africa: Organization of African Unity, African Union, New Partnership for Africa's Development and the African Court. Netherlands Quarterly of Human Rights, 23, 381. https://doi.org/10.1177/016934410502300304

Murray, R., \& Long, D. (2015). Implementation of the Findings of the African Commission on Human and Peoples' Rights (p. 50). Cambridge: Cambridge University Press.

Mutua, M. (1995). The Banjul Charter and the African Cultural Fingerprint: An Assessment of the Language of Duties. Virginia Journal of International Law, 35, 339.

Odinkalu, C. A. (2001). The Role of Case and Complaints Procedures in the Reform of the African Regional Human Rights System. African Human Rights Law Journal, 1, 226.

Odinkalu, C. A. (2002). Africa's Regional Human Rights System: Recent Development and Jurisprudence. Human Rights Law Review, 2, 99-106. https://doi.org/10.1093/hrlr/2.1.99

Odinkalu, C. A. (2010). African Commission on Human and Peoples' Rights: Recent Cases. Human Rights Law Review, 1, 98.

Shelton, D. L. (2007). Introduction: Law, Non-Law and the Problem of Soft Law. In D. L. Shelton (Ed.), Compliance and Commitment: The Role of Non-Binding Norms in the International Legal System (p. 1). Oxford: Oxford University Press.

Singh, S. (2009). The Impact of Clawback Clauses on Human and Peoples' Rights in Africa. African Security Review, 18, 95-104. https://doi.org/10.1080/10246029.2009.9627561

Viljoen, F. (2009). An Introduction to the Protocol to the African Charter on Human and Peoples' Rights on the Rights of Women in Africa. Washington and Lee Journal of Civil Rights and Social Justice, 16, 11. 
Viljoen, F. (2012). International Human Rights Law in Africa (pp. 269). Oxford: Oxford University Press. https://doi.org/10.1093/acprof:osobl/9780199645589.001.0001

Viljoen, F., \& Baimu, E. (2004). Courts for Africa: Considering the Co-Existence of the African Court on Human and Peoples' Rights and the African Court of Justice. Netherlands Quarterly of Human Rights, 22, 241. https://doi.org/10.1177/016934410402200205

Viljoen, F., \& Louw, L. (2004). The Status of the Findings of the African Commission: From Moral Persuasion to Legal Obligation. Journal of African Law, 48, 1-22. https://doi.org/10.1017/S0021855304481017

Viljoen, F., \& Louw, L. (2007). State Compliance with the Recommendations of the African Commission on Human and People's Rights, 1994-2004. American Journal of International Law, 101, 1-34.

Zysset, A. (2017). The ECHR and Human Rights Theory: Reconciling the Moral and the Political Conceptions (p. 217). London: Routledge.

Ayeni, V. O. (2016). The Impact of the African Charter and the Maputo Protocol in Selected African States (p. 6). Pretoria: Pretoria University Law Press. 